\title{
Public Health Promotion and Education with Hypertension Awareness in West Jakarta Indonesia
}

\author{
Erlina Puspitaloka Mahadewi ${ }^{1 *}$, Intan Silviana Mustikawati ${ }^{2}$, Ade Heryana ${ }^{3}$ \\ Arman Harahap ${ }^{4}$ \\ ${ }^{1,2,3}$ Public Health Study Program, Faculty of Health Sciences, \\ Universitas Esa Unggul, Jakarta Indonesia. \\ ${ }^{4}$ Universitas Labuhanbatu, Sumatera Utara, Indonesia \\ * Corresponding Author: \\ Email: erlina.puspitaloka@esaunggul.ac.id
}

\begin{abstract}
.
The present study reports are the comprehensive study on the awareness of hypertension which is a dangerous disease with an increase in blood pressure above normal values. According to the study, hypertension is an increase in systolic blood pressure of about 140 $\mathrm{mmHg}$ or diastolic pressure of about $90 \mathrm{mmHg}$. Hypertension is a problem that needs to be watched out for, because there are no specific signs of hypertension and some people still feel healthy to carry out their usual activities. This is what makes hypertension a silent killer by data of Indonesia Ministry of Health, 2018, people will realize they have hypertension when the symptoms they feel are getting worse and go to health services. The purpose of this health promotion is to provide information and education to the public about hypertension and its prevention in Tegal Alur Village, Kali Deres District, West Jakarta. Health promotion activities are carried out online using the online via zoom meet application with lecture, question and answer and discussion methods. To determine the effectiveness of health promotion activities, such healthy living community movement or known as Germas, to the community members were given a questionnaire before (pre-test) and after the activity (post-test). Based on the post-test results, it was found that there was an increase in knowledge about hypertension. Plans and achievement targets for the followup to the implementation of this activity can be carried out in collaboration with all parties, namely the government, campuses and the wider surrounding community to create a community movement in creating behavior and awareness of hypertension prevention itself.
\end{abstract}

Keywords: community member, healthy living community movement (germas), health promotion, hypertension and its prevention.

\section{INTRODUCTION}

Hypertension in the elderly is often found because most middle-aged or elderly people are at risk of developing hypertension. Hypertension in the elderly is caused by a decrease in the elasticity of the aortic wall, thickening of the heart valves which makes the valves stiff, decreased ability to pump the heart, loss of elasticity of peripheral blood vessels, and increased peripheral vascular resistance. The cause of the elderly suffering from hypertension is due to the decline in body work functions. Another factor that causes hypertension in the elderly is lifestyle, such as consumption of junk food, cigarettes, alcohol, and lack of exercise. On junk food that is high in calories, high in fat, low in fiber, and high in sodium or salt. High fat and sodium or salt are one of the factors that cause hypertension, then cigarettes contain nicotine which triggers the adrenal glands to release epinephrine or adrenaline causing 
constriction of blood vessels and making the heart pump harder due to higher pressure. Alcohol consumption can increase the acidity of the blood which makes the blood thicker and the heart becomes harder to pump, while lack of exercise is an independent risk factor for chronic disease and is estimated overall can cause death globally[1].

Among pandemic hypertension is an increase in blood pressure above normal values. According to the study of hypertension is an increase in systolic blood pressure of about $140 \mathrm{mmHg}$ or diastolic pressure of about $90 \mathrm{mmHg}$. Hypertension is a problem that needs to be watched out for, because there are no specific signs of hypertension and some people still feel healthy to carry out their usual activities. This is what makes hypertension a silent killer and people will realize they have hypertension when the symptoms they feel are getting worse and go to health services[2]. Therefore, the health promotion target that is planned to be carried out at this community service is a target for the community, especially adults and the elderly, where in adulthood and also the elderly usually someone tends not to maintain their diet because usually the elderly they still do not feel various health problems so it is not uncommon they also do not pay attention to the nutritional intake of the food they eat. One way that can be done to change people's knowledge, attitudes, and behavior is by doing health promotion[3].

There are several definitions of health promotion. The Ottawa Charter in 1986, as a result of the formulation of the International Health Promotion Conference in Ottawa, Canada, states that "Health Promotion is the process of enabling people to control over and improve their health" World Health Organization, in maintaining and improving their health. The healthcare experts defined health promotion as any combination of health education and economic, political and organizational interventions designed to facilitate behavioral change and an environment conducive to health. The Victoria-Australia Health Foundation, formulated the definition of health promotion as follows: "Health Promotion is a program are design to bring about 'change' within people, organizations, communities and their environment" by Victorian Health Promotion Foundation in year 1997. This definition emphasizes that health promotion is programs designed to bring about change or improvement in society, organizations and the environment[4]. In Indonesia, the Directorate of Health Promotion and Community Empowerment of the Ministry of Health of the Republic of Indonesia defines health promotion as an effort to improve the ability of the community through a learning process from, by, for and with the community, so that they can help themselves, as well as develop community-based activities, in accordance with local socio-cultural conditions and supported by health-oriented public policies by Ministry of Health (MOH) in Indonesia. The purpose of health promotion is to enable people to maintain and improve their health and to create a condition, namely behavior and an environment that is conducive to health. Health promotion that is part of the public health program in Indonesia must be able to realize the vision of health development in Indonesia, so that health promotion can be formulated as "People who are willing and able to maintain and improve their health"[5]. 
According to the goals of health promotion consist of program objectives (longterm goals) which are a reflection of the social and epidemiological phases in the form of statements about what will be achieved in a certain period related to health status; educational goals (medium-term goals) namely learning that must be achieved in order to achieve the desired behavior; and behavioral goals (short-term goals) which describe the behavior to be achieved in overcoming health problems[6]. In general, the targets of promotion activities can be grouped into three, namely primary, secondary, and tertiary targets by Ministry of Health, 2020. The primary targets in health promotion are the community consisting of the head of the family for general health problems and chronic diseases; pregnant and lactating women for $\mathrm{MCH}$ issues (mother and child health); children for adolescent health, and so on[7]. Then the secondary targets in health promotion are people who have influence in the community and can be used as role models, such as community leaders, religious leaders, traditional leaders, and others. While the tertiary target in health promotion, namely the decision makers or policy makers both at the central and regional levels, is the tertiary target of health education. Health Promotion by grounding the Community Movement or GERMAS is one part of our actions of public health experts to participate with the government in improving the health status of the community[8]. Based on demographic changes in society without considering lifestyle changes, it is estimated that hypertension sufferers will increase rapidly in the next 15 years, especially in developing countries. At present, efforts to control hypertension have not yet occupied the main priority scale in health services, although it is known that the negative impacts it causes are quite large, including stroke for the brain, coronary heart disease for the heart blood vessels and for the heart muscle. Given the increasing incidence of hypertension and the dangers of complications, it is necessary to disseminate information about hypertension, including blood pressure checks so that adults and the elderly in West Jakarta can monitor their health conditions more easily. The purpose of health education about hypertension is to provide information so that adults and the elderly have awareness of the symptoms and prevention of hypertension in order to increase knowledge, attitudes, and practices regarding healthy living in the general public[9]. To promote Germas and Healthy Living with online seminars and education, targeting community members around the campus, especially with the highest rank of community with hypertention, on Kayu Besar, Tegal Alur Village, Kali Deres District, West Jakarta which has been carried out through zoom meetings. This is in accordance with the government movement in increasing promotive and preventive efforts. The spirit and purpose that is brought is to create or change people's behavior to implement the community movement in the application of a healthy lifestyle, as well as participate in helping prevent Covid-19 which is still a pandemic in Indonesia until now[10]. In the current state of the pandemic, the implementation of health promotion is carried out virtually or online by zoom. This activity is a collaboration between students and lecturers from from the 
Public Health Study Program at the Faculty of Health Sciences, Esa Unggul University Jakarta.

\section{METHODS}

The study research type is analytic observational study with case control approach. The subjects in this study amounted to 20 respondents, consisting of 20 cases and 20 controls. The study was conducted in Kayu Besar, Tegal Alur Village, Kali Deres District, West Jakarta. Samples were taken by simple random sampling. Data were obtained through questionnaires and direct interviews and physical examinations of blood pressure, height, and weight measurement. Data analysis was carried out in stages include univariate analysis, bivariate analysis with chi-square test, and multivariate analysis using multiple logistic regression test of backward stepwise method-likelihood ratio on statistic program[11].

The community service activities and event are carried out on residents and family members of Kayu Besar, Tegal Alur Village, Kali Deres District, West Jakarta Indonesia, which was held online using the zoom meet application on January, 2021. Prior to the activity, a site survey and discussions with related parties had been carried out. The following is an overall activity and schedule to preparation and report which will be carried out in stages from December 2020 to February 2021. The implementation of this community service program also consists of 3 (three) stages:

\section{Preparation Stage}

At the preparatory stage, an assessment of the problems faced by the community partners and the head of the RT, the community elders, was carried out by searching data on the health problems of the residents of Jalan Kayu Besar, so that health promotion activities could be carried out in the areas most at risk of health problems. the. In addition, preparations were also made in the form of: making proposals for community service activities, licensing activity locations, and making activity instruments.

\section{Implementation Stage}

Activities that will be carried out on partners are health promotion activities regarding clean and healthy living behavior about hypertension to increase knowledge, attitudes, and practices regarding attitudes regarding clean and healthy (PHBS). The communication, information, and education (KIE) media used in the activity are presentation materials using microsoft power point. It is hoped that there will be an increase the community members knowledge and attitudes regarding attitudes regarding clean and healthy (PHBS) after participating in the activity, so that participants can practice PHBS for themselves and their families. The intervention that will be given is in accordance with the previous research roadmap, namely implementing activities that aim to improve the health of the community members and family of Jalan Kayu Besar.

\section{Report Review and Evaluation Stage}


The latest stage is writing and dissemination of activity results. At this stage, activity reports are written and the results are disseminated to interested parties, such as the head of community, member and family of the community, university and others. Outcome for the future, residents or community members can practice clean and healthy living behavior in the environment and to improve health and prevent

\section{Input: Priority problems faced by Partners}

Increased awareness and prevention of hypertension behavior in adults and the elderly in the community during the pandemic, and others

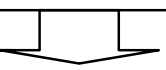

Process: Summary of the solution process for Abdimas kegiatan activities Community Movement Health promotion regarding hypertension in the general public around the university to improve knowledge about hypertension, attitudes, and PHBS in the community well during the nandemic

hypertension in particular.

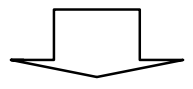

Output: Outcomes and Benefits

Increased knowledge of the general public around the UEU campus about hypertension and degenerative diseases.

Benefits: Community members can practice clean and healthy living behaviors in

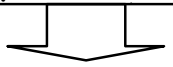

Outcome: Hope for the future

Residents can practice clean and healthy living behavior in the environment and to

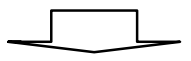

\section{Implementation and the evaluation:}

The evaluation was carried out by giving pre-test and post-test to the residents to find out their understanding of the hypertension and PHBS material given

Fig 1. An overview of science and knowledge of program evaluation results transferred to the community

\section{RESULT AND DISCUSSION}

Evaluation of the implementation of activities is very important to see the results or outputs of activities. To determine the effectiveness and level of achievement of the training, a step is carried out, namely evaluation. Evaluation is very important to study because evaluation will measure the level of achievement of the training program carried out, so that it will provide feedback for the continuity of the next training program. Based on the post-test results, it was found that there was an increase in the knowledge of the residents of Jalan Kayu Besar regarding hypertension. Prior to the presentation of the material, they did not know what healthy behaviors needed to be 
applied to prevent hypertension and the benefits of implementing PHBS at home and in the environment. However, after providing information on the two related topics, their knowledge increased. Thus, it can be concluded that health promotion activities can increase people's knowledge about hypertension and healthy living behavior. This is in accordance with the health promotion carried out, that there is an increase in knowledge of certain members of the community after health education efforts have been carried out. The materials provided in this community health promotion activities regarding clean and healthy living behavior during a pandemic include everything related to the prevention and education of hypertension, efforts to improve healthy behavior, understanding and benefits of clean and healthy living behavior, targets for healthy living behaviors, behavioral problems clean and healthy living, indicators of clean and healthy living behavior. At the beginning of the event, community members were given a questionnaire (pre-test) first and the questionnaire was distributed again after the event was over (post-test). It aims to see the effectiveness of health promotion, whether there is an increase in knowledge before and after health promotion activities. The types of outcomes from pre-post test for health promotion regarding hypertension and PHBS carried out in the community on Kayu Besar, Tegal Alur Village, Kali Deres District, West Jakarta, are:

1. The number of community members living on Kayu Besar, Tegal Alur Village, Kali Deres subdistrict who participated in the activity was at least $75 \%$ of the total population, approximately more than 20 family members representatives.

2. Increased knowledge and attitudes of citizens regarding awareness and prevention of hypertension, which is at least $70 \%$.

3. There is a follow-up plan for community education activities around West Jakarta again.

Statistical tests indicate a risk factor for hypertension, this is regarding with the values results of in the community of Kayu Besar is the age $(\mathrm{p}=0,0025 ; \mathrm{OR}=11,30$ and $95 \%$ $\mathrm{CI}=1,446-95,553)$, family history $(\mathrm{p}=0,002$; $\mathrm{OR}=14,378$ and $95 \% \mathrm{CI}=4,036-$ $52,232)$, smoking $(\mathrm{p}=0,012$; OR $=9,820$ and $95 \% \mathrm{CI}=1,730-51,833)$, and obesity $(\mathrm{p}=0,017 ; \mathrm{OR}=9,151$ and $95 \% \mathrm{CI}=1,794-46,420)$, while the consumption of gender, salt consumption, fat consumption, and activity factor has no effect. This is proved to be a risk factor for hypertension were age, family history, smoking, and obesity, while the factors that are not proven as risk factors for hypertension are gender, salt consumption, fat consumption, and activity of the community members.

\section{CONCLUSION}

\section{Conclusion}

Health promotion activities regarding hypertension take place smoothly with the goal of increasing public knowledge. This activity needs to be held continuously with several improvements such as the use of teaching aids that are more attractive, informative and educative. So that some of the physiological processes of hypertension can be seen with the naked eye. The best coordination from the head of community who facilitated online community service activities, also to the lecturers who 
gave permission, advised and for recommendations so that the activities took place in an orderly manner.

\section{Suggestions}

It is hoped that the family and community members, will always pay attention to the condition of the adult and the elderly community. Who can be suffer from hypertension through the support provided by the family by more often having discussions with the elderly about nutritional problems, experienced by the elderly and families not using terms that are difficult for the elderly to understand in an effort to improve nutritional status, because with the support provided, it allows the family to function optimally so that it can help improve the health of family members, especially during the pandemic covid-19 and next in the future.

\section{ACKNOWLEDGMENTS}

The authors are grateful to for all the team members for advices, the head of community included all family members (community) in Kayu Besar, Tegal Alur Village, Kali Deres District, West Jakarta for invaluable support and collaborations.

\section{REFERENCES}

[1] WHO, "Together on the road to universal health coverage: A call to action," World Heal. Organ., 2017.

[2] D. A. Rosman and J. C. Apfeld, "The economics of health care," in An Introduction to Health Policy: A Primer for Physicians and Medical Students, 2013.

[3] World Health Organization, "Noncommunicable Diseases Country Profiles 2018," World Health Organization, 2018. .

[4] F. Di Gennaro et al., "Coronavirus diseases (COVID-19) current status and future perspectives: A narrative review," International Journal of Environmental Research and Public Health. 2020, doi: 10.3390/ijerph17082690.

[5] L. Guinness, V. Wiseman, and D. Wonderling, Introduction to Health Economics Second Edition. 2011.

[6] R. Khana, M. M. Singh, F. Damanhoori, and N. Mustaffa, "Investigating the importance of implementing ethical value on a healthcare system within a social media context," Int. J. Innov. Creat. Chang., vol. 12, no. 5, 2020.

[7] R. Agustina et al., "Universal health coverage in Indonesia: concept, progress, and challenges," The Lancet. 2019, doi: 10.1016/S0140-6736(18)31647-7.

[8] H. T. Indra Rachmad Darmawan, "Refleksi Implementasi Jaminan Kesehatan Nasional pada Pelayanan Kedokteran Gigi di Fasilitas Kesehatan Tingkat Pertama Kota Tangerang Tahun 2017,” Jurnal Kebijakan Kesehatan Indonesia : JKKI. 2017.

[9] L. Trisnantoro, "Universal health coverage and medical industry in 3 Southeast Asian countries," BMC Public Health, 2014, doi: 10.1186/1471-2458-14-s1-i3.

[10] L. Gurrieri and J. Drenten, "Visual storytelling and vulnerable health care consumers: normalising practices and social support through Instagram," J. Serv. Mark., vol. 33, no. 6, 2019, doi: 10.1108/JSM-09-2018-0262.

[11] T. Şahin, S. Ocak, and M. Top, "Analytic hierarchy process for hospital site selection," Heal. Policy Technol., 2019, doi: 10.1016/j.hlpt.2019.02.005. 